\title{
Modification of the claim: limits and their impact on the availability of justice in the Russian Federation
}

\author{
Lyudmila Valerievna Starodubova ${ }^{1 *}$, Leonardo Aurelio Ingannamorte ${ }^{2}$, Igor Vladimirovich \\ Mashtakov $^{1}$, Olga Sergeevna Lapshina ${ }^{1}$ and Golib Nurullo Kodirzoda ${ }^{3}$ \\ ${ }^{1}$ Tolyatti State University, Department of Civil Law and Process, Institute of Law, Tolyatti, Russia \\ ${ }^{2}$ Tolyatti State University, Institute of Law, Tolyatti, Russia \\ ${ }^{3}$ Academy of the Ministry of Internal Affairs of the Republic of Tajikistan Department of State Legal \\ Disciplines, Faculty No. 2, Dushanbe, Tajikistan
}

\begin{abstract}
The purpose of the study is to prove the need to lift restrictions in civil proceedings and proceedings in arbitration courts in terms of the limits of modification of the claim and to provide the applicant with the possibility of simultaneous modification of the subject and the basis of the claim while maintaining their previously stated legally protected interest. Certainly, this may be possible only and exclusively with the approval of the judge, as well as with the preservation of all procedural guarantees for the defendant. The methodological basis of the research is the general, general scientific and private scientific methods of cognition used by legal science in the object-subject sphere of cognition of the general theory of law. In addition, a number of synthetic, integrative methods of research are used, which are included in the methodology of interdisciplinary science, which is relevant for modern socio-humanitarian science. The results of the study are the justification that these limits in some cases can completely block the applicant's access to the mechanisms of justice. The authors argue that this is unacceptable since it violates both the subjective right of the applicant to a defense, and one of the most important principles of justice is the principle of accessibility. The authors also considered the issue of the validity of the limits of the modification of the claim. The novelty of the work is in the results of the analysis of the practice and the alleged hypothetical situations in which the existence of limits for the modification of the claim does not allow the applicant to defend its rights and legitimate interests, as in the identified causes, conditions, and consequences of such phenomena.
\end{abstract}

Keywords: civil procedure, arbitration procedure, justice accessibility, claim modification, judicial protection

\section{Introduction}

\footnotetext{
${ }^{1}$ Corresponding author: starodubova72@bk.ru
} 
The debate about the theoretical and practical aspects of the concept of access to justice has not subsided for decades. Such interest in the topic is fair - the availability of justice is the guarantor of justice itself, the guarantor of the protection of the rights, freedoms, and legitimate interests of citizens and organizations within the legal framework [1,2].

The issue to be addressed in this article is the problem of the impact of the limits of the claim modification on the availability of justice in the Russian Federation. As the current procedural legislation does not contain regulatory definitions of the claim and its elements, modifications of the claim, and identical claims, when studying the relevant topics, the works of the authors-processualists were studied [3].

Modification of the claim is a change in the elements of the claim, which are currently understood as the subject, basis, and content of the claim [4]. Some authors distinguish the fourth element - the parties to the claim [5]. The limits of modification to be discussed in the article are described in the current civil and arbitration procedural legislation of the Russian Federation - "change the basis or subject of the claim", which prohibits the applicant to modify the two mentioned elements of the claim at the same time.

\section{Methods}

The methodological basis of the research is the general, general scientific, and private scientific methods of cognition used by legal science in the object-subject sphere of cognition of the general theory of law. In addition, a number of synthetic, integrative methods of research are used, which are included in the methodology of interdisciplinary science, which is relevant for modern socio-humanitarian science.

\section{$3 \quad$ Results and discussion}

Despite the absence of regulative definitions, there are explanations of the higher courts, from which it follows that "a change in the subject of the claim refers to a change in the substantive claim of the applicant to the defendant. A change in the basis of the claim refers to a change in the circumstances on which the applicant bases its claim against the defendant" [6].

The mentioned limits, from the perspective of the legislator, are connected to the fact that in the case of a simultaneous change in the basis and subject of the claim will result in a completely different claim, protecting a completely different legal interest. Thus, the legislator protects the defendant from abuse of the right on the part of the applicant. However, it is not so clear, because by protecting the interests of the defendant, the legislator has jeopardized both the interests of the applicant and the interests of justice, as a result of a violation of which there will be a violation of the concept of accessibility of justice.

To begin with, it is believed that changing the subject and the basis of the claim separately is often impossible, since the modification of one element inevitably entails the modification of the second [7].

Also, a similar point of view is held by Rozhkova, who believes that "almost any change in the subject of the claim entails at least a partial change in its grounds, even if the applicant did not pursue such a goal" [8].

Undoubtedly, any theoretical assumption requires its practical confirmation, in connection with which here is a specific example from judicial practice. The Central District Court of Togliatti, in one of its decisions taken in 2019, allowed a simultaneous modification of the basis and subject of the claim. In its initial claims, the applicant asked only to terminate the contract of sale in connection with the sale of low-quality goods with 
obvious defects. During the trial, the applicant demanded the recovery of a penalty, psychological damage, court costs, as well as a fine of $50 \%$ of the amount awarded by the court [9]. It is obvious that such a modification of the subject matter of the claim entailed a modification of the grounds - the new grounds were: violation of the terms of the concluded contract, psychological damage, the fact of court costs, as well as the defendant's failure to comply with the requirements of the law on non-compliance with the requirements of the consumer on a voluntary basis. This modification was allowed by the court, and later a decision was made in this case.

In another case, the Central District Court of Tyumen allowed modification of the subject of the claim, which, in addition to the previously stated termination of the contract of sale and the application of penalties, included claims for recovery of the value of the defective goods (delivered not under the previously mentioned contract of sale, but under another contract with the defendant) and compensation for moral damage [10].

To sum up, it is believed that in the vast majority of cases, the modification of the object leads to the modification of the base and vice versa. But, despite this conclusion, the restriction on the simultaneous change of the subject and the basis of the claim is justified to some extent and aims at protecting the rights of the defendant. However, in some cases, this restriction does not protect the rights of the defendant, but infringes the rights of the applicant and harms the interests of justice.

Speaking of the problem and considering the limits of modification of the claim in the context of their impact on the degree of qualitative implementation of the principle of accessibility of justice, it should be mentioned that the presence of these limits may in some situations unreasonably block access for applicants to judicial protection mechanisms.

First of all, it should be mentioned that the idea of accessible justice seems to be an independent principle of justice. This opinion is based on the position of prof. Semenov, who developed the concept of accessibility of justice as one of the procedural principles in the second half of the $20^{\text {th }}$ century [11]. This position is also shared by a number of modern authors [11-13]. The use of the principle of accessibility of justice is revealed in a situation of no inadequate and biased obstacles to access to justice mechanisms $[14,15]$. Thus, the existence of anything that in one way or another unreasonably and adversely affects the availability of judicial protection is a violation of the principle of access to justice.

The existence of limits of modification of the claim is a factor of procedural insufficiency as a part of the legal category [16].

An example of such a situation from practice is the case considered by the Frunzensky District Court of Saratov. The applicant filed a claim for termination of the contract of sale in connection with the sale of a product with a defect - a phone that does not turn on. At the same time, the seller refused to take any actions to eliminate the mentioned defect, not properly responding to the applicant's attempts to settle the dispute in a pre-trial manner. During the examination conducted by the applicant, it turned out that the cause of the defect was a manufacturing defect of the system board. Since it was impossible to replace the system board and eliminate the defect due to the lack of the necessary board in the free sale, the applicant was forced to file a claim for termination of the contract of sale, since he bought a product with an irremediable defect. During the trial, it became clear that the defect was fixable, so the plaintiff attempted to amend the claim to require the seller to remedy the product defect without compensation. However, the court refused such a change, since it implied a modification of both the subject and the basis of the claim. As a result of the court's consideration of the case, the satisfaction of the applicant's original claims was denied [17]. Thus, the restriction on the simultaneous modification of the subject and the basis of the claim led to the infringement of the applicant's right to judicial protection of its rights and legitimate interests. 
These examples reveal situations when the applicant should have had the opportunity to modify both the subject matter and the grounds of the claim to protect its rights, freedoms and legitimate interests. But such actions are directly prohibited by the current procedural law, which is illogical since if they were committed, the applicant would pursue the protection of exactly the legal interest that was initially declared.

As a confirmation of the mentioned position, here is a quotation of the opinion of the Presidium of the Supreme Arbitration Court of the Russian Federation, stated in Resolution No. 161/10 dated 11.05.2010, according to which the court's acceptance of clarified claims with a change in the subject and basis of the claim is not a reason for the cancellation of the relevant decision by a higher court if such clarifications follows from the effectiveness of judicial protection [18].

If there is a court practice that allows, within certain limits, simultaneous changes in the subject and the basis of the claim, and there are objective facts and reasonable arguments confirming the need for the possibility of modifying several elements of the claim, then this should be fixed as a procedural rule in the current legislation of the Russian Federation.

Of course, being subjected to simultaneous modification in terms of changing the subject and the ground, the claim experiences a mutation, in some way turning into a completely different claim. But is this sufficient for the legislator to block such an opportunity for the applicant? It is believed that it is necessary to proceed primarily from the need to protect those interests of the applicant, under the pretext of which the appeal to judicial authorities occurred.

The increase in the volume of procedural opportunities of the applicant should, according to V.M. Sherstyuk, be accompanied by guarantees of protection of the defendant - postponement of proceedings, delivery of a copy of the modified claim, availability of the defendant to present its objections in the response to the claim and time to prepare for the process, etc. [11].

\section{Conclusion}

In conclusion, it is necessary to consider the need to change the provisions of Article 39 of the Civil Procedure Code of the Russian Federation and Article 49 of the Arbitration Procedure Code of the Russian Federation in terms of allowing the possibility of simultaneous modification of both the basis and the subject of the claim. In order to solve this problem, it is possible to add new parts to these articles without correcting the existing ones. The following version of the text of Article 39 of the Civil Procedure Code and Article 49 of the Arbitration Procedure Code is proposed:

"With the consent of the court, it is permissible to simultaneously change the subject and the basis of the claim while maintaining the legal interest previously stated by the applicant in situations where such a change is necessary for the exercise of the applicant's right to judicial protection."

The clause "with the consent of the court" was included in order to protect the defendant from the possibility of abuse of this right by the applicant. And, of course, as it was mentioned before, in the case of such a modification of the claim, the rights of the defendant shall be protected with the provision of appropriate procedural powers postponing the proceedings, serving a copy of the modified claim, having the opportunity to present their objections in the response to the claim and time to prepare for the process, etc.

After studying this article, the authors propose to enter into an open scientific discussion to collectively solve this problem - perhaps there are other ways to preserve the applicant's right to judicial protection in situations of acute need to simultaneously change the subject and the basis of his claim. Only through the joint efforts of the scientific community and the 
legislator is it possible to solve the most acute problems of the modern legal system of the Russian Federation.

\section{References}

1. I.I. Chernykh, Act. Probl. Rus. Law, 1(74), 28-32 (2017)

2. W. Lucy, Oxford J. Leg. Stud. 40(2), 377-402 (2020)

3. S.K. Zagainova, Judicial acts in the mechanism of the implementation of judicial power in civil and arbitration proceedings (Volters Kluver, Moscow, 2007)

4. V.V. Gruzdev, Legal Sci. 3, 31-35 (2011)

5. A.A. Mokhov, I.V. Vorontsova, S.Yu. Semenova, Grazhdanskii protsess (grazhdanskoe protsessualnoe pravo) Rossii: ucheb. posobie [Civil procedure (civil procedure law) of Russia: manual] (LAW FIRM CONTRACT, LLC, Moscow, 2017)

6. Postanovlenie Plenuma VAS RF ot 31 oktyabrya 1996 g. № 13 (red. ot 09.07.1997 g.) "O primenenii Arbitrazhnogo protsessualnogo kodeksa Rossiiskoi Federatsii pri rassmotrenii del v sude pervoi instantsii" [Resolution of the Plenum of the Supreme Arbitration Court of the Russian Federation dated October 31, 1996 No. 13 (ed. 09.07.1997) "On the Application of the Arbitration Procedural Code of the Russian Federation in the consideration of cases in the court of First Instance"]. Accessed on: June 24, 2021. [Online]. Available: http:http://base.garant.ru/10136773/

7. I.A. Prikhodko, Dostupnost pravosudiya $v$ arbitrazhnom i grazhdanskom protsesse: osnovnye problemy [Accessibility of justice in arbitration and civil proceedings: main problems], Doctoral thesis in Legal Science (Russian Academy of Justice, Moscow, 2005)

8. M.A. Rozhkova, Bul. Supr. Arbitr. Court Rus. Fed. 9, 106-110 (2000)

9. Reshenie Tsentralnogo raionnogo suda g. Tolyatti? 2-4029/2019 2-4029/2019 M-3335/2019 M-3335/2019 ot 30 avgusta 2019 g. po delu № 2-4029/2019 [Decision of the Central District Court of Togliatti ? 2-4029/2019 2-4029/2019 M-3335/2019 M-3335/2019 dated August 30, 2019 in case No. 2-4029/2019]. Accessed on: June 24, 2021. [Online]. Available: https://sudact.ru/regular/doc/XDI2IyzX5bNs/

10. Reshenie Tsentralnogo raionnogo suda g. Tyumeni? 2-7127/2019 2-7127/2019 M-5992/2019 M-5992/2019 ot 22 avgusta 2019 g. po delu № 2-7127/2019 [Decision of the Central District Court of Tyumen? 2-7127/2019 2-7127/2019 M-5992/2019 M-5992/2019 dated August 22, 2019 in case No. 2-7127/2019]. Accessed on: June 24, 2021. [Online]. Available: https://sudact.ru/regular/doc/JeffvkRtm1rv/

11. V.M. Sherstyuk, Arbitr. Pract. 2, 35-46 (2003)

12. S.V. Baranov, Dostupnost pravosudiya kak uslovie realizatsii konstitutsionnogo prava na sudebnuyu zashchitu v Rossiiskoi Federatsii [Accessibility of justice as a condition for the implementation of the constitutional right to judicial protection in the Russian Federation], PhD thesis in Legal Science (Russian Academy of Public Administration under the President of the Russian Federation, Moscow, 2011)

13. J.H. Gerards, L.R. Glas, Netherlands Quart. Human Rights, 35(1), 11-35 (2017)

14. L.A. Ingannamorte, Problemy dostupnosti pravosudiya [Problems of accessibility of justice], Bachelor's Thesis. (Tolyatti, 2020)

15. Deborah L.R., Scott L.C., Georgetown J. Leg. Ethics, 30, 485-500 (2017) 
16. L.V. Starodubova, L.A. Ingannamorte, Vector nauki Tolyatti State Univ., Ser.: Legal Sci. 4(43), 29-34 (2020)

17. Reshenie Frunzenskogo raionnogo suda g. Saratova № 2-549/2019

2-549/2019 M-368/2019 M-368/2019 ot 16 aprelya 2019 g. po delu № 2-549/2019 [Decision of the Frunzensky District Court of Saratov No. 2-549/2019

2-549/2019 M-368/2019 M-368/2019 dated April 16, 2019 in case No. 2-549/2019]. Accessed on: June 24, 2021. [Online]. Available:

https://sudact.ru/regular/doc/Ew8ELAO4411R/

18. Postanovlenie Prezidiuma Vysshego Arbitrazhnogo Suda RF ot 11 maya 2010 g. № 161/10 [Resolution of the Presidium of the Supreme Arbitration Court of the Russian Federation No. 161/10 dated May 11, 2010]. Accessed on: June 24, 2021. [Online]. Available: http://www.garant.ru/products/ipo/prime/doc/1695378/ 